\title{
Pertumbuhan berbagai Macam Bahan Eksplan Kentang Atlantik secara In Vitro dengan Perlakuan IAA
}

\section{The Growth of Various Kinds of Material Explants of Atlantic Potato by using in Vitro with IAA Treatments}

\author{
Anisah Shofhatur Rohmah*, Ellen Rosyelina Sasmita, Endah Wahyurini \\ Departement of Agrotechnology, Faculty of Agriculture, Universitas Pembangunan Nasional Veteran Yogyakarta, Yogyakarta, Indonesia \\ *Corresponding author: shofhaturrohmah@gmail.com
}

Received: March 1, 2021; Accepted: March 27, 2021; Published: October 31, 2021

\begin{abstract}
The Atlantic potato is the potato used in the food industry. Conventional potato propagation is constrained by the accumulation of pathogens, decreased quality of seed, and low propagation rates. Plant tissue culture is one of the appropriate method that can be used to solve these problem. This study aims to determine the most appropriate IAA concentration for various kinds of Atlantic potato explants. The study was conducted in July - August 2020 at the Tissue Culture Laboratory of the Pembangunan Nasional Veteran Yogyakarta University. Completely Randomized Design (CRD) was used as an experimental design with different combination of the concentration of IAA at 0,$5 ; 1$; and $1,5 \mathrm{ppm}$ and the kind of explants namely shoot, middle, and base of the plantlet). Observation was conducted at 8 weeks after planting. Variables observed were plantlet height, number of nodes, number of branches, number of leaves, leave colour, root length, and dry weight of plantlet. The results showed that $1 \mathrm{ppm}$ concentration of IAA with the middle of the plantlet could increase the number of node and the number of leaves of Atlantic potato plantlets. $0.5 \mathrm{ppm}$ concentration of IAA were able to increase the plantlet height, number of branches, root length, and dry weight of Atlantic potatoes. Explants from the middle of the plantlet were able to increase the number of side shoots of Atlantic potato plantlets.
\end{abstract}

Keywords: auxin; plant growth regulator; tissue culture

Cite this as: Rohmah, A. S., Sasmita, E. R. \& Wahyurini, E. (2021). Pertumbuhan berbagai macam bahan eksplan kentang atlantik secara in vitro dengan perlakuan IAA. Agrosains : Jurnal Penelitian Agronomi, 23(2), 72-79. DOI: http://dx.doi.org/10.20961/agsjpa.v23i2.49027

\section{PENDAHULUAN}

Kentang kultivar Atlantik merupakan kentang untuk bahan baku industri pangan seperti french fries dan chips. Kentang Atlantik bukan kultivar asli Indonesia, namun merupakan hasil introduksi dari Wisconsin Amerika Serikat, memiliki rata-rata hasil 8 hingga 20 ton/ha, berumur 100 hari, kulit ubi berwarna kuning, daging ubi berwarna putih dan mempunyai kandungan karbohidrat $16 \%$. Kentang varietas ini memiliki kadar pati tinggi namun rendah gula dan air (Basuki et al., 2020).

Produksi kentang di Indonesia mengalami penurunan dari tahun 2015 hingga tahun 2017. Kenaikan produksi pada tahun berikutnya pun belum dapat mengungguli produksi kentang tertinggi pada 10 tahun terakhir yaitu pada tahun 2014 yang mencapai 1.347.818 ton (Hidayat et al., 2018). Kentang diperbanyak secara aseksual dengan umbi. Umbi kentang melalui berbagai proses pembentukan yang kompleks. Rendahnya rata-rata produktivitas kentang nasional dipengaruhi oleh terbatasnya penggunaan benih kentang bermutu oleh petani. Sebagian besar petani menggunakan benih umbi kentang dari generasi berikutnya, yaitu hasil panen yang dimanfaatkan sebagai benih. Perbanyakan kentang dengan cara ini membuat sulitnya memproduksi benih yang bebas penyakit. Produksi benih kentang secara konvensional terkendala dengan akumulasi patogen, penurunan kualitas, serta rendahnya tingkat perbanyakan. Perlu dilakukan upaya yang tepat guna meningkatkan produktivitas kentang Atlantik (Amarullah et al., 2019; Meng et al., 2020; Wang et al., 2018). Teknik kultur jaringan tanaman telah banyak dikembangkan untuk menghasilkan benih kentang yang bebas hama, penyakit, dan virus dengan kebutuhan bahan awal yang sedikit. Benih yang dihasilkan bersifat seragam sama seperti induknya yang dapat digunakan sebagai sumber perbanyakan dengan biaya penyediaan benih relatif murah dibandingkan benih impor (Joseph et al., 2018). Kultur jaringan tanaman merupakan metode mengkulturkan bagian-bagian tanaman seperti sel, jaringan, atau organ menggunakan media buatan pada kondisi aseptik serta lingkungan yang terkontrol (Méndez-Hernández et al., 2021). Teori dasar kultur jaringan adalah totipotensi. Sifat totipotensi adalah kemampuan sel tumbuhan untuk memproduksi embrio menjadi individu baru (Aguilar-Hernández \& LoyolaVargas, 2018).

Keberhasilan multiplikasi tunas kentang ditentukan oleh penggunaan media dasar yang dikombinasikan 
dengan penambahan zat pengatur tumbuh (Munggarani et al., 2018). Hal ini diperkuat dengan Ashrafzadeh (2020) yang menyatakan bahwa keberhasilan dari teknik kultur jaringan salah satunya dipengaruhi oleh komposisi media kultur serta penambahan zat pengatur tumbuh yang sesuai. Penggunaan zat pengatur tumbuh di dalam kultur jaringan tergantung pada tujuan atau arah pertumbuhan yang diinginkan. Pembentukan organ terjadi akibat interaksi antara zat pengatur tumbuh eksogen yang ditambahkan pada media dengan zat pengatur tumbuh endogen pada tumbuhan (Naz et al., 2017). Zat pengatur tumbuh yang umum digunakan dalam kultur jaringan adalah auksin dan sitokinin. Penggunaan zat pengatur tumbuh auksin berfungsi untuk merangsang pembelahan sel, pemanjangan dan diferensiasi sel (Liu et al., 2020). Salah satu jenis auksin yang sering digunakan adalah Indole Acetic Acid (IAA). Berperan dalam pembelahan, diferensiasi, dan pemanjangan sel tumbuhan (Enders \& Strader, 2015). IAA memiliki sifat kimia yang stabil dan memiliki mobilitas dalam tanaman yang rendah sehingga efektif digunakan. Penambahan auksin ke dalam media kultur dapat meningkatkan konsentrasi zat pengatur tumbuh endogen di dalam sel, sehingga menjadi faktor pemicu dalam proses pertumbuhan dan perkembangan jaringan tanaman (Li et al., 2019). IAA 1 ppm mampu menghasilkan jumlah daun lebih banyak serta akar yang lebih panjang dibandingkan dengan jenis auksin lainnya pada kentang varietas Granola (Hilman et al., 2019). IAA 0,5 ppm mampu mendukung pertumbuhan panjang akar (Khalid et al., 2004; Tohge et al., 2013).

Pemilihan eksplan yang digunakan tergantung dari tipe respon pertumbuhan yang diinginkan. Eksplan dapat diinduksi untuk morfogenesis langsung maupun tidak langsung. Morfogenesis langsung dapat menghasilkan tunas adventif yang selanjutnya dapat diinduksi menjadi planlet (Hou et al., 2015). Seluruh bagian planlet dapat digunakan sebagai eksplan untuk menghindari pemborosan bahan tanam. Eksplan pucuk kentang yang ditanam pada media MS menghasilkan pertumbuhan terbaik pada parameter jumlah daun dan jumlah akar (Furnawanthi et al., 2017). Eksplan yang digunakan dalam penelitian ini adalah bagian pucuk, bagian tengah, dan bagian pangkal. Saat ini belum banyak penelitian yang membahas mengenai pengaruh IAA terhadap pertumbuhan eksplan kentang Atlantik. Penelitian ini bertujuan untuk mendapatkan konsentrasi IAA yang tepat pada berbagai macam bahan eksplan kentang Atlantik.

\section{BAHAN DAN METODE}

Penelitian dilaksanakan pada bulan Juli 2020 sampai Agustus 2020 di Laboratorium Kultur Jaringan Jurusan Agroteknologi Fakultas Pertanian UPN Veteran Yogyakarta. Alat yang digunakan meliputi timbangan analitik, gelas beker $1 \mathrm{~L}$, magnetic stirrer, kompor gas, botol, pinset, skalpel, blade, laminar air flow, lampu bunsen, hand sprayer, petridish, dan autoclave. Bahan yang digunakan meliputi planlet kentang Atlantik umur 4 minggu, akuades steril, kertas $\mathrm{pH}, \mathrm{HCl} 0,1 \%, \mathrm{KOH} \mathrm{0,1 \% .}$ media MS, IAA, BAP, alkohol $70 \%$, alumunium foil, dan tisu.

Penelitian ini menggunakan Rancangan Acak Lengkap (RAL) faktorial yang terdisi dari 2 faktor. Faktor pertama yaitu konsentrasi IAA yang terdiri atas 3 aras, yaitu: A1 (0,5 ppm IAA), A2 (1 ppm IAA), A3 (1,5 ppm
IAA). Faktor kedua yaitu macam bahan eksplan yang terdiri atas 3 aras, yaitu: B1 (bagian pucuk), B2 (bagian tengah), B3 (bagian pangkal). Diperoleh 9 kombinasi perlakuan yang diulang sebanyak 3 kali sehingga diperoleh 162 botol kultur yang berisi satu buah eksplan tiap botolnya.

Pelaksanaan penelitian meliputi (1) Sterilisasi alatalat seperti botol kultur, petridish, skalpel, dan pinset menggunakan autoclave yang diatur hingga suhu $121^{\circ} \mathrm{C}$ dengan tekanan 15 psi selama 45 menit. (2) Pembuatan media yaitu menggunakan media MS (Murashige dan Skoog) dengan menambahkan zat pengatur tumbuh berupa BAP 1 ppm dan IAA sesuai dengan perlakuan yaitu 0,$5 ; 1$; dan 1,5 ppm. $\mathrm{pH}$ disesuaikan hingga 5,8 . Apabila $\mathrm{pH}$ masih terlalu rendah ditambahkan $\mathrm{KOH}$ $0,1 \%$, sedangkan bila $\mathrm{pH}$ terlalu tinggi ditambahkan $\mathrm{HCl}$ $0,1 \%$. Dimasukkan agar-agar kemudian dipanaskan sambil terus diaduk hingga mendidih. Setelah mendidih, dituangkan media ke dalam botol kultur, ditutup menggunakan alumunium foil kemudian disterilkan menggunakan autoclave dengan suhu $121^{\circ} \mathrm{C}$ dan tekanan 15 psi selama 30 menit. (3) Penanaman eksplan dilakukan dengan cara stek mikro. Eksplan yang digunakan adalah planlet kentang Atlantik berumur 4 MST. Planlet dipotong pada bagian pucuk, bagian tengah, dan bagian pangkal sepanjang $2 \mathrm{~cm}$ dengan jumlah buku sebanyak 1 kemudian dihilangkan seluruh daunnya menggunakan scalpel. Eksplan ditanam dalam botol berisi media sesuai perlakuan. Penanaman dilakukan di dalam laminar air flow. Botol kultur kemudian disimpan dalam ruang inkubasi. (4) Pemeliharaan dilakukan dengan menyemprotkan alkohol $70 \%$ pada botol dan sekitarnya agar terhindar dari kontaminan. (5) Pengamatan dilakukan pada 8 MST dengan parameter tinggi planlet, jumlah buku, jumlah tunas samping, jumlah daun, warna daun, panjang akar, dan bobot kering planlet.

Data hasil pengamatan dianalisis menggunakan uji Analysis of Variance pada jenjang nyata 5\%. Untuk mengetahui beda nyata antar perlakuan maka dilakukan uji lanjut dengan Duncan's Multiple Range Test (DMRT) $\alpha=5 \%$.

\section{HASIL DAN PEMBAHASAN}

Analisis sidik ragam tinggi planlet menunjukkan tidak ada interaksi antar perlakuan, sedangkan secara tunggal kosentrasi IAA menunjukkan pengaruh nyata terhadap tinggi planlet (Tabel 1).

Tabel 1. Tinggi Planlet Kentang Atlantik pada Berbagai Konsentrasi IAA dan Berbagai Macam Bahan Eksplan (cm)

\begin{tabular}{ccccc}
\hline \multirow{2}{*}{$\begin{array}{c}\text { Konsentrasi } \\
\text { IAA (ppm) }\end{array}$} & $\begin{array}{c}\text { Macam Bahan Eksplan } \\
\text { Pucuk } \\
\text { (B1) }\end{array}$ & $\begin{array}{c}\text { Bagian } \\
\text { Tengah } \\
\text { (B2) }\end{array}$ & $\begin{array}{c}\text { Bagian } \\
\text { Pangkal } \\
\text { (B3) }\end{array}$ & $\begin{array}{c}\text { Rata- } \\
\text { rata }\end{array}$ \\
\hline $0,5(\mathrm{~A} 1)$ & 12,22 & 9,82 & 6,62 & $9,56 \mathrm{a}$ \\
$1(\mathrm{~A} 2)$ & 9,81 & 7,62 & 10,00 & $9,14 \mathrm{a}$ \\
$1,5(\mathrm{~A} 3)$ & 4,37 & 3,67 & 3,76 & $3,93 \mathrm{~b}$ \\
\hline Rata-rata & 8,80 & 7,04 & 6,79 & $(-)$ \\
\hline
\end{tabular}

Keterangan: Angka-angka yang diikuti huruf yang sama pada kolom atau baris menunjukkan tidak ada beda nyata berdasarkan DMRT taraf $5 \%$. Tanda (-) menunjukkan tidak ada interaksi. Data ditransformasikan dalam $\sqrt{(\text { data }+0,5)}$. 


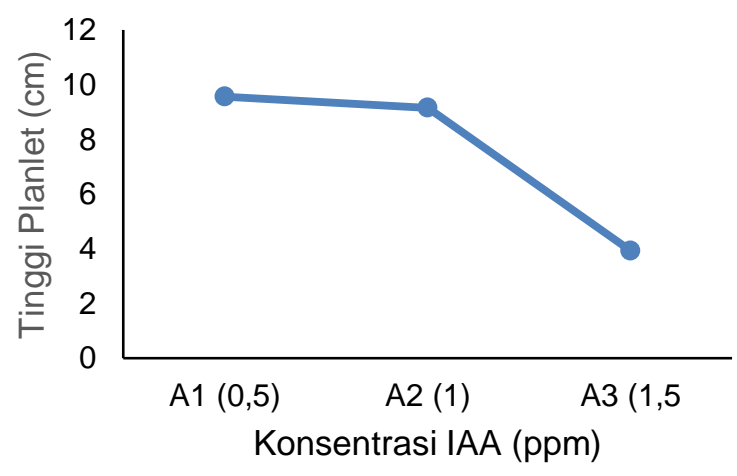

Gambar 1. Tinggi Planlet Kentang Atlantik pada Berbagai Konsentrasi IAA

Pada Tabel 1. terlihat bahwa perlakuan konsentrasi IAA 0,5 ppm dan $1 \mathrm{ppm}$ menghasilkan rata-rata tinggi planlet yang paling baik. IAA dapat merangsang pertumbuhan sel (Vandenbussche et al., 2020). Hasil penelitian ini menunjukkan bahwa peningkatan konsentrasi IAA yang diberikan tidak sejalan dengan pertumbuhan tinggi planlet (Gambar 1). Hal ini diduga berkaitan dengan sifat hormon dan zat pengatur tumbuh yang pada umumnya aktif pada konsentrasi yang sangat rendah, sedangkan pada konsentrasi yang sangat tinggi justru dapat mengakibatkan kematian pada tanaman (Zhang et al., 2005). Konsentrasi yang sangat rendah dari senyawa kimia tertentu yang diproduksi oleh tanaman dapat memacu atau menghambat pertumbuhan atau diferensiasi pada berbagai macam sel-sel tumbuhan dan dapat mengendalikan perkembangan bagian-bagian organ yang berbeda pada tumbuhan (Ludwig-Müller, 2011). Rendahnya hormon eksogen yang diperlukan berkaitan dengan adanya hormon endogen yang sudah mencukupi kebutuhan eksplan sehingga penambahan hormon eksogen tidak berpengaruh nyata.

Tabel 2. Jumlah Tunas Samping Planlet Kentang Atlantik pada Berbagai Konsentrasi IAA dan Berbagai Macam Bahan Eksplan (buah)

\begin{tabular}{ccccc}
\hline \multirow{2}{*}{$\begin{array}{c}\text { Konsentrasi } \\
\text { IAA (ppm) }\end{array}$} & \multicolumn{3}{c}{ Macam Bahan Eksplan } & \\
\cline { 2 - 4 } & $\begin{array}{c}\text { Bagian } \\
\text { Pucuk } \\
\text { (B1) }\end{array}$ & $\begin{array}{c}\text { Bagian } \\
\text { Tengah } \\
\text { (B2) }\end{array}$ & $\begin{array}{c}\text { Bagian } \\
\text { Pangkal } \\
\text { (B3) }\end{array}$ & $\begin{array}{c}\text { Rata- } \\
\text { rata }\end{array}$ \\
\hline 0,5 (A1) & 1,44 & 1,66 & 1,78 & $1,63 \mathrm{a}$ \\
1 (A2) & 1,44 & 2,22 & 1,33 & $1,67 \mathrm{a}$ \\
1,5 (A3) & 0,11 & 1,11 & 0,55 & $0,59 \mathrm{~b}$ \\
\hline Rata-rata & $1,00 \mathrm{q}$ & $1,66 \mathrm{p}$ & $\begin{array}{c}1,22 \\
\text { pq }\end{array}$ & $(-)$ \\
\hline
\end{tabular}

Keterangan: Rerata yang diikuti huruf yang sama pada kolom atau baris menunjukkan tidak ada beda nyata, berdasarkan DMRT taraf $5 \%$. Tanda (-) menunjukkan tidak ada interaksi. Data ditransformasikan dalam $\sqrt{(\text { data }+0,5)}$

Analisis sidik ragam jumlah tunas samping menunjukkan tidak ada interaksi antar perlakuan, sedangkan secara tunggal pemberian konsentrasi IAA dan asal eksplan memberikan pengaruh nyata terhadap jumlah tunas samping kentang Atlantik (Tabel 2). Secara tunggal, konsentrasi IAA 0,5 ppm dan $1 \mathrm{ppm}$ mampu menghasilkan jumlah tunas samping lebih banyak dibandingkan dengan kosentrasi 1,5 ppm. Hasil penelitian ini menunjukkan peningkatan konsentrasi IAA yang diberikan tidak sejalan dengan pertumbuhan tunas samping (Gambar 2). Diketahui bahwa penambahan
IAA secara in vitro secara signifikan dapat mengurangi pertumbuhan tunas lateral (Zahid et al., 2021).

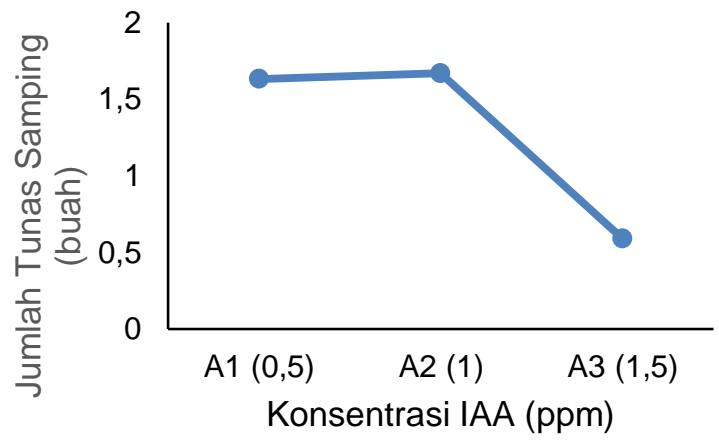

Gambar 2. Jumlah Tunas Samping Planlet Kentang Atlantik pada Berbagai Konsentrasi IAA (buah)

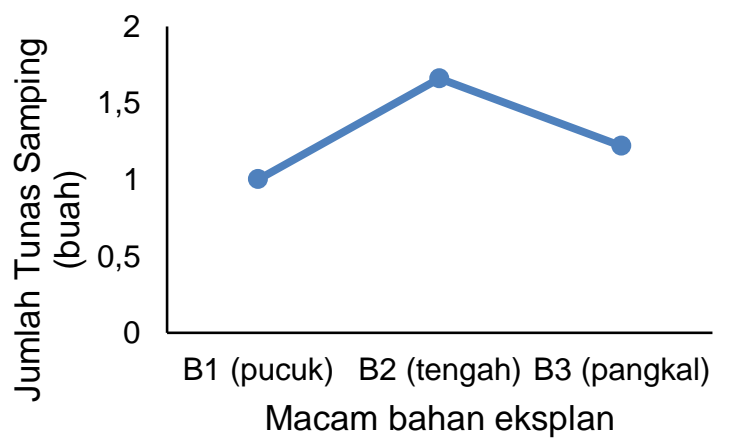

Gambar 3. Jumlah Tunas Samping Planlet Kentang Atlantik pada Berbagai Macam Bahan Eksplan (buah)

Perlakuan macam bahan eksplan bagian tengah mampu menghasilkan jumlah tunas samping lebih banyak dibandingkan dengan bagian pucuk namun tidak berbeda nyata dengan bagian bagian pangkal. Bagian pangkal jumlah tunas sampingnya tidak berbeda nyata dengan perlakuan (Gambar 3). Hal ini dipengaruhi oleh adanya dominansi apikal. Dominansi apikal merupakan keadaan pada tanaman di mana tunas utama mendominasi dan menghambat pertumbuhan tunas lainnya (Parab et al., 2021). Ujung pucuk yang tumbuh menghasilkan hormone penghambat, yaitu auksin yang bergerak ke bawah di dalam batang dan menghambat pertumbuhan tunas aksilar. Apabila pucuk dihilangkan maka akan mendorong pembentukan cabang (MartínezLópez et al., 2021).

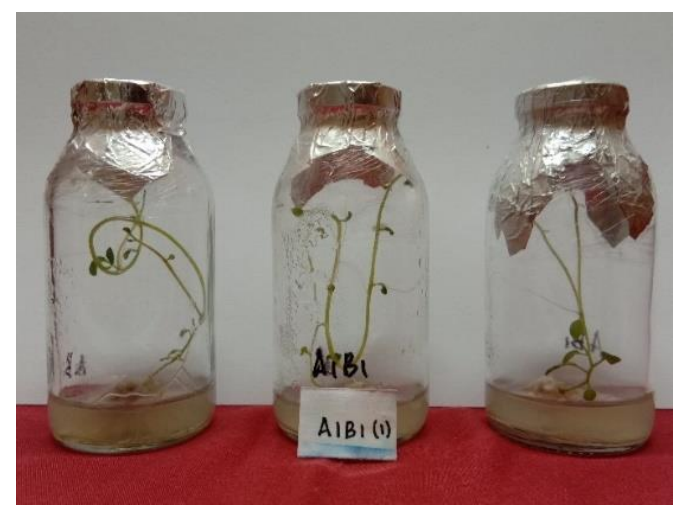

Gambar 4. Pertumbuhan planlet kentang Atlantik perlakuan A1B1 (0,5 ppm IAA+bagian pucuk) pada 8 MST 
Tabel 3. Jumlah Buku Planlet Kentang Atlantik pada Berbagai Konsentrasi IAA dan Berbagai Macam Bahan Eksplan (buah)

\begin{tabular}{|c|c|c|c|c|}
\hline \multirow{2}{*}{$\begin{array}{c}\text { Konsentr } \\
\text { asi IAA } \\
\text { (ppm) }\end{array}$} & \multicolumn{3}{|c|}{ Macam Bahan Eksplan } & \multirow{2}{*}{$\begin{array}{c}\text { Rata- } \\
\text { rata }\end{array}$} \\
\hline & $\begin{array}{c}\text { Bagian } \\
\text { Pucuk (B1) }\end{array}$ & $\begin{array}{c}\text { Bagian } \\
\text { Tengah } \\
\text { (B2) }\end{array}$ & $\begin{array}{l}\text { Bagian } \\
\text { Pangkal } \\
\text { (B3) }\end{array}$ & \\
\hline $0,5(\mathrm{~A} 1)$ & $10,56 a b$ & $6,89 \mathrm{~d}$ & $10,00 \mathrm{abc}$ & 9,15 \\
\hline 1 (A2) & $9,78 a b c$ & 12,78 a & $12,67 \mathrm{a}$ & 11,74 \\
\hline $1,5(\mathrm{~A} 3)$ & $7,22 \mathrm{~cd}$ & $9,00 \begin{array}{l}b c \\
d\end{array}$ & $9,33 \mathrm{bcd}$ & 8,52 \\
\hline $\begin{array}{l}\text { Rata- } \\
\text { rata }\end{array}$ & 9,19 & 9,56 & 10,67 & $(+)$ \\
\hline
\end{tabular}

Keterangan: Rerata yang diikuti huruf yang sama pada kolom atau baris menunjukkan tidak ada beda nyata, berdasarkan DMRT taraf 5\%. Tanda (-) menunjukkan tidak ada interaksi. Data ditransformasikan dalam $\sqrt{(\text { data }+0,5)}$.

Analisis sidik ragam jumlah buku dan jumlah daun menunjukkan terdapat interaksi antar perlakuan (Tabel 3). Kombinasi perlakuan konsentrasi IAA 0,5 ppm dengan macam bahan eksplan bagian pucuk dan bagian tengah, kombinasi perlakuan konsentrasi IAA 1 ppm dengan macam bahan eksplan bagian pucuk, bagian tengah, dan bagian pangkal jumlah daunnya nyata lebih banyak dibandingkan dengan perlakuan lainnya. Kombinasi perlakuan konsentrasi IAA $1 \mathrm{ppm}$ dengan macam bahan eksplan bagian tengah dan pangkal jumlah daunnya nyata lebih banyak dibandingkan dengan perlakuan lainnya (Gambar 4). Daun merupakan organ penting tumbuhan sebagai tempat fotosintesis. Hasil dari proses fotosintesis ini berupa oksigen dan karbohidrat dimana karbohidrat digunakan sebagai sumber karbon dan cadangan makanan untuk mendukung pertubuhan dan perkembangan tumbuhan (Lv et al., 2020). Semakin banyak jumlah daun, maka karbohidrat yang terbentuk makin banyak sehingga mampu mendukung pertumbuhan tanaman lebih optimal. Jumlah daun pada kentang setara dengan jumlah bukunya, sehingga pembentukan daun dan buku berkaitan satu sama lain (Wang et al., 2018). Pembentukan jumlah buku (Gambar 5) dan daun (Gambar 6) dipengaruhi oleh kemampuan eksplan untuk menyerap hara yang terdapat pada media, namun zat pengatur tumbuh eksogen juga memiliki peran penting untuk pertumbuhannya (Jahn et al., 2021). Hasil penelitian ini mengindikasikan bahwa penambahan perlakuan IAA 0,5 dan $1 \mathrm{ppm}$ mampu merangsang pertumbuhan jumlah buku dan jumlah daun. Penambahan zat pengatur tumbuh pada media kultur jaringan dengan konsentrasi yang tepat dapat meningkatkan pembelahan sel dalam proses morfogenesis dan organogenesis (Furnawanthi et al., 2017; Sevillano et al., 2018). Selain itu, banyaknya jumlah daun (Tabel 4) dan jumlah buku sejalan dengan banyaknya jumlah tunas samping. Perlakuan konsentrasi IAA 1 ppm dan perlakuan macam bahan eksplan bagian tengah dan bagian pangkal memiliki jumlah tunas samping yang paling baik yang disebabkan karena adanya pengaruh dominansi apikal dimana apabila bagian pucuk dihilangkan maka tunas lateral akan terbentuk. Hal inilah yang membuat kombinasi perlakuan macam bahan eksplan bagian tengah dan bagian pangkal memiliki jumlah buku dan daun lebih banyak.

Kombinasi perlakuan konsentrasi IAA 1,5 ppm dengan macam bahan eksplan bagian pucuk, bagian tengah, dan bagian pangkal memiliki jumlah daun lebih rendah dibandingkan dengan perlakuan lainnya. Bagian pangkal planlet tersusun atas jaringan tua yang kurang aktif membelah bila dibandingkan dengan jaringan muda tanaman yang terdapat pada ujung tanaman. Selain itu, penambahan zat pengatur tumbuh dengan konsentrasi $1,5 \mathrm{ppm}$ dapat menghambat pembentukan jaringan, dalam hal ini adalah pertumbuhan daun. Auksin bekerja pada konsentrasi rendah. Konsentrasi auksin yang tinggi mempunyai efek menghambat sehingga banyaknya auksin dalam tanaman perlu dikontrol dengan ketat (Kong et al., 2021; Xu et al., 1998).

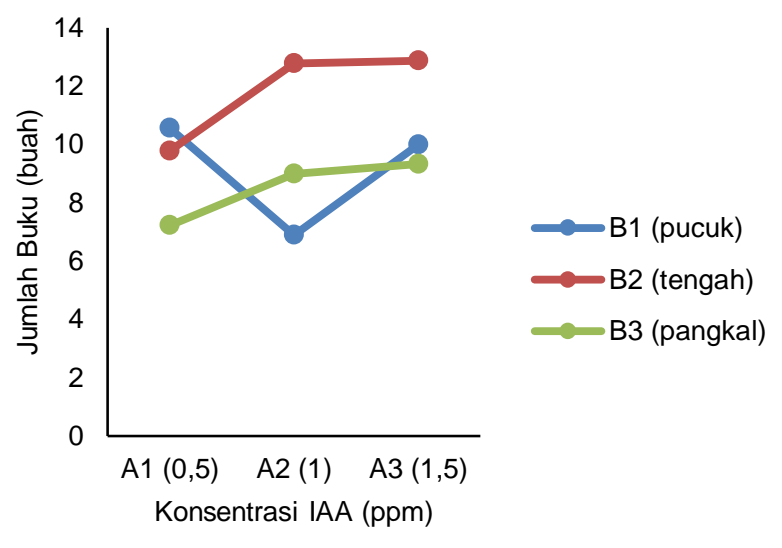

Gambar 5. Jumlah Buku Planlet Kentang Atlantik pada Berbagai Konsentrasi IAA dan Berbagai Macam Bahan Eksplan

Pembentukan klorofil pada daun mampu meningkatkan laju fotosintesis pada planlet (Moriwaki et al., 2019). Hasil fotosintesis yang berupa karbohidrat dimanfaatkan tumbuhan sebagai sumber energi dan cadangan makanan. Kombinasi perlakuan yang digunakan diduga mengandung unsur hara makro dan mikro yang cukup untuk merangsang pertumbuhan klorofil pada planlet. Analisis sidik ragam panjang akar menunjukkan tidak ada interaksi antar perlakuan, sedangkan secara tunggal konsentrasi IAA menunjukkan pengaruh nyata terhadap panjang akar. Panjang akar memungkinkan tanaman untuk menjangkau wilayah yang lebih jauh untuk mencari unsur hara dan air pada media tumbuhnya serta penting untuk aklimatisasi pada lingkungan ex vitro.

Tabel 4. Jumlah Daun Planlet Kentang Atlantik pada Berbagai Konsentrasi IAA dan Berbagai Macam Bahan Eksplan (helai)

\begin{tabular}{ccccc}
\hline \multirow{2}{*}{$\begin{array}{c}\text { Konsentr } \\
\text { asi IAA } \\
\text { (ppm) }\end{array}$} & $\begin{array}{c}\text { Bagian } \\
\text { Pucuk (B1) }\end{array}$ & $\begin{array}{c}\text { Magian } \\
\text { Tengah } \\
(\mathrm{B} 2)\end{array}$ & $\begin{array}{c}\text { Bagian } \\
\text { Pangkal (B3) }\end{array}$ & $\begin{array}{c}\text { Rata- } \\
\text { rata }\end{array}$ \\
\cline { 2 - 4 } $0,5(\mathrm{~A} 1)$ & $11,00 \mathrm{bcd}$ & 8,11 def & $9,56 \mathrm{cde}$ & 9,56 \\
$1(\mathrm{~A} 2)$ & $11,67 \mathrm{bc}$ & 16,56 a & $13,56 \mathrm{ab}$ & 13,93 \\
$1,5(\mathrm{~A} 3)$ & $5,89 \mathrm{f}$ & 8,00 def & 7,11 ef & 7,00 \\
\hline Rata-rata & 9,52 & 10,89 & 10,07 & $(+)$ \\
\hline
\end{tabular}

Keterangan: Rerata yang diikuti huruf yang sama pada kolom atau baris menunjukkan tidak ada beda nyata, berdasarkan DMRT taraf 5\%. Tanda (-) menunjukkan tidak ada interaksi. Data ditransformasikan dalam $\sqrt{(\text { data }+0,5)}$. 


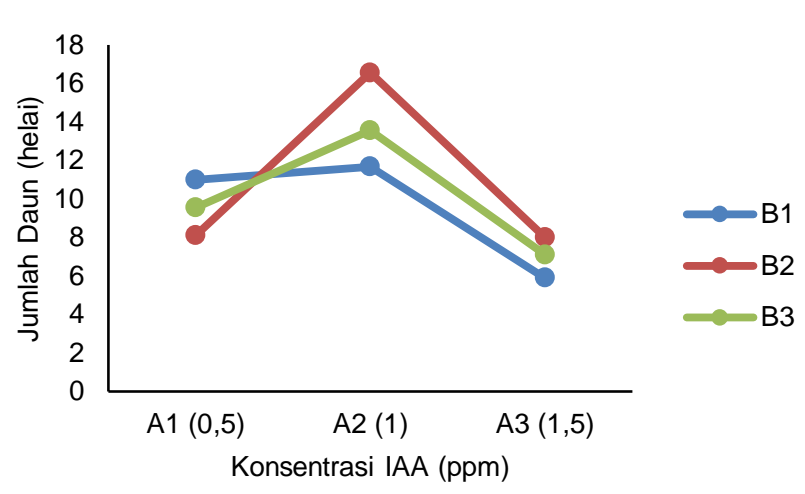

Gambar 6. Jumlah Daun Planlet Kentang Atlantik pada Berbagai Konsentrasi IAA dan Berbagai Macam Bahan Eksplan
Parameter warna daun diamati menggunakan Munshell Colour Chart for Plant Tissue. Hasil pengamatan menunjukkan terdapat perbedaan warna pada masing-masing kombinasi perlakuan, namun 7,5 GY 4/6 merupakan warna yang paling dominan (Tabel 5). Warna daun pada berbagai kombinasi perlakuan menghasilkan warna hijau muda dan hijau tua. Warna hijau pada daun kentang disebabkan karena terbentuknya klorofil yang berasal dari unsur nitrogen $(\mathrm{N})$, Magnesium (Mg), dan Mangan (Mn). Nitrogen merupakan unsur penyusun klorofil, sedangkan Magnesium dan Mangan merupakan bagian dari klorofil (Dewanto et al., 2019).

Tabel 5. Warna Daun Planlet Kentang Atlantik pada Berbagai Konsentrasi IAA dan Berbagai Macam Bahan Eksplan

\begin{tabular}{lcc}
\hline \multicolumn{1}{c}{ Kombinasi Perlakuan } & Warna Daun & Visual Warna \\
\hline A1B1 (IAA 0,5 ppm + bagian pucuk) & $7,5 G Y 4 / 6$ & Keterangan \\
A1B2 (IAA 0,5 ppm + bagian tengah) & $7,5 G Y 5 / 6$ & Hijau agak gelap \\
A1B3 (IAA 0,5 ppm + bagian pangkal) & $7,5 G Y 5 / 6$ & Hijau agak gelap \\
A2B1 (IAA 1 ppm + bagian pucuk) & $7,5 G Y 5 / 6$ & Hijau agak gelap \\
A2B2 (IAA 1 ppm + bagian tengah) & $7,5 G Y 4 / 6$ & Hijau gelap \\
A2B3 (IAA 1 ppm + bagian pangkal) & $7,5 G Y 5 / 6$ & Hijau agak gelap \\
A3B1 (IAA 1,5 ppm + bagian pucuk) & $7,5 G Y 5 / 6$ & Hijau agak gelap \\
A3B2 (IAA 1,5 ppm + bagian tengah) & $7,5 G Y 6 / 8$ & Hijau tua \\
A3B3 (IAA 1,5 ppm + bagian pangkal) & $7,5 G Y 6 / 8$ & Hijau tua \\
\hline
\end{tabular}

Keterangan: $\mathrm{GY}=$ Green Yellow

Tabel 6. Panjang Akar Planlet Kentang Atlantik pada Berbagai Konsentrasi IAA dan Berbagai Macam Bahan Eksplan (cm)

\begin{tabular}{ccccc}
\hline \multirow{2}{*}{$\begin{array}{c}\text { Konsentrasi } \\
\text { IAA (ppm) }\end{array}$} & $\begin{array}{c}\text { Macam Bahan Eksplan } \\
\text { Bucuk (B1) }\end{array}$ & \begin{tabular}{c} 
Rata- \\
rata \\
\cline { 2 - 4 } Tengah \\
(B2)
\end{tabular} & $\begin{array}{c}\text { Bagian } \\
\text { Pangkal } \\
\text { (B3) }\end{array}$ & \\
\hline $0,5(\mathrm{~A} 1)$ & 7,09 & 4,07 & 4,64 & $5,27 \mathrm{a}$ \\
$1(\mathrm{~A} 2)$ & 4,07 & 3,84 & 4,51 & $4,14 \mathrm{a}$ \\
$1,5(\mathrm{~A} 3)$ & 0,63 & 0,34 & 0,43 & $0,47 \mathrm{~b}$ \\
\hline Rata-rata & 3,93 & 2,75 & 3,20 & $(-)$ \\
\hline
\end{tabular}

Keterangan: Rerata yang diikuti huruf yang sama pada kolom atau baris menunjukkan tidak ada beda nyata berdasarkan DMRT taraf $5 \%$. Tanda (-) menunjukkan tidak ada interaksi. Data ditransformasikan dalam $\sqrt{(\text { data }+0,5)}$.

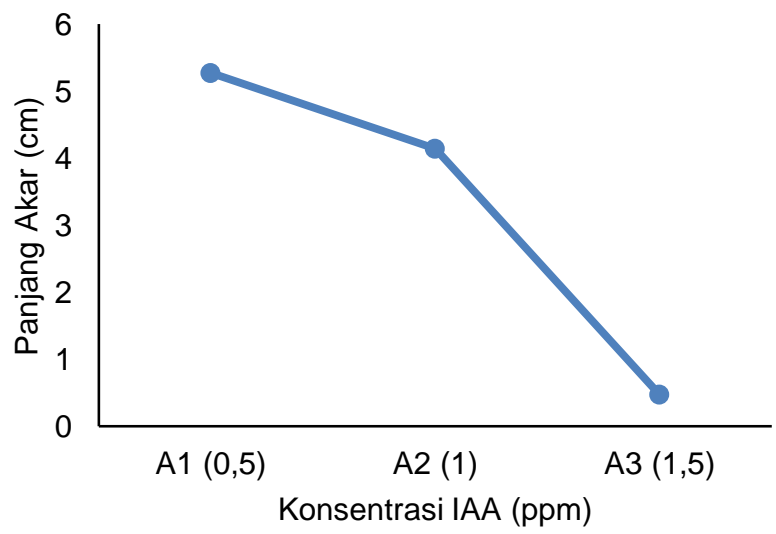

Perlakuan konsentrasi IAA 0,5 ppm dan $1 \mathrm{ppm}$ (Tabel 6) menghasilkan rata-rata panjang akar yang terbaik (Gambar 7). IAA dengan konsentrasi 0,5 ppm menghasilkan akar paling panjang dibanding dengan perlakuan dengan konsentrasi yang lebih tinggi (Zhang et al., 2005). Penambahan IAA 1 ppm mampu mendukung pemanjangan akar kentang Granola dibandingkan dengan auksin lain pada konsentrasi sama. IAA telah terbukti mampu mendukung berbagai tahap perkembangan akar (Nawaz et al., 2021).

Analisis sidik ragam bobot kering planlet menunjukkan tidak ada interaksi antar perlakuan (Tabel 7). Bobot kering tanaman (Gambar 8) menunjukkan akumulasi senyawa organik yang mampu disintesis tanaman dari senyawa anorganik, terutama air dan karbon dioksida. Unsur hara yang telah diserap akar memberi kontribusi terhadap pertambahan bobot kering tanaman (Naz et al., 2017). Pertumbuhan sel tanaman mempengaruhi bobot kering. IAA berperan dalam pembelahan, diferensiasi, dan pemanjangan sel tumbuhan (Enders \& Strader, 2015). Perlakuan IAA 0,5 ppm menghasilkan bobot kering yang lebih berat dibanding dengan perlakuan lainnya. Respon jaringan terhadap penambahan auksin tergantung dari konsentrasi dan jaringan itu sendiri (Ryu et al., 2005). Konsentrasi auksin yang tinggi mempunyai efek menghabat (Bawa et al., 2020). 
Tabel 7. Bobot Kering Planlet Kentang Atlantik pada Berbagai Konsentrasi IAA dan Berbagai Macam Bahan Eksplan (mg)

\begin{tabular}{ccccc}
\hline \multirow{2}{*}{$\begin{array}{c}\text { Konsentra } \\
\text { si IAA } \\
(\text { ppm) }\end{array}$} & \multicolumn{3}{c}{ Macam Bahan Eksplan } & Rata-rata \\
\cline { 2 - 4 } & $\begin{array}{c}\text { Bagian } \\
\text { Pucuk (B1) }\end{array}$ & $\begin{array}{c}\text { Bagian } \\
\text { Tengah } \\
(\mathrm{B} 2)\end{array}$ & $\begin{array}{c}\text { Bagian } \\
\text { Pangkal } \\
\text { (B3) }\end{array}$ & \\
\hline 0,5 (A1) & 28,31 & 26,03 & 19,89 & $24,75 \mathrm{a}$ \\
1 (A2) & 17,68 & 15,15 & 16,76 & $16,53 \mathrm{~b}$ \\
1,5 (A3) & 13,16 & 10,90 & 12,36 & $12,14 \mathrm{~b}$ \\
\hline Rata-rata & 19,72 & 17,36 & 16,33 & $(-)$ \\
\hline
\end{tabular}

Keterangan: Rerata yang diikuti huruf yang sama pada kolom atau baris menunjukkan tidak ada beda nyata berdasarkan DMRT taraf $5 \%$. Tanda (-) menunjukkan tidak ada interaksi. Data ditransformasikan

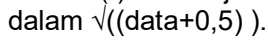

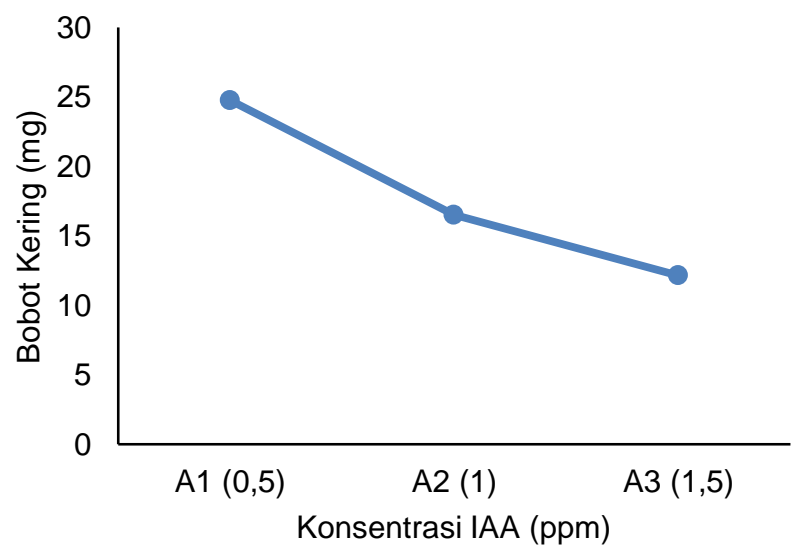

Gambar 8. Bobot Kering Planlet Kentang Atlantik pada Berbagai Konsentrasi IAA dan Berbagai Macam Bahan Eksplan (mg)

\section{KESIMPULAN}

Konsentrasi IAA 1 ppm dengan macam bahan eksplan bagian tengah secara interaksi dapat meningkatkan jumlah buku dan jumlah daun planlet kentang Atlantik. Konsentrasi IAA 0,5 ppm dapat meningkatkan tinggi planlet, jumlah tunas samping, panjang akar, dan bobot kering planlet kentang Atlantik. Macam bahan eksplan bagian tengah dapat meningkatkan jumlah tunas samping planlet kentang Atlantik

\section{DAFTAR PUSTAKA}

Aguilar-Hernández, V., \& Loyola-Vargas, V. M. (2018). Advanced proteomic approaches to elucidate somatic embryogenesis. Frontiers in Plant Science, 871(November).

https://doi.org/10.3389/fpls.2018.01658

Amarullah, M. R., Sudarsono, ., \& Amarillis, S. (2019). Produksi dan Budidaya Umbi Bibit Kentang (Solanum tuberosum L.) di Pangalengan, Bandung, Jawa Barat. Buletin Agrohorti, 7(1), 93-99. https://doi.org/10.29244/agrob.v7i1.24753

Ashrafzadeh, S. (2020). In vitro grafting-twenty-first century's technique for fruit tree propagation. Acta Agriculturae Scandinavica Section B: Soil and Plant Science, 70(5), 404-405. https://doi.org/10.1080/09064710.2020.1754452

Basuki, R. S., Khaririyatun, N., Sembiring, A., Nurmalinda, N., \& Arshanti, I. W. (2020). Studi Adopsi Benih Kentang Bebas Virus Varietas Granola L. dari Balai Penelitian Tanaman Sayuran di Kabupaten Garut, Jawa Barat. Jurnal Hortikultura,
29(2)

241.

https://doi.org/10.21082/jhort.v29n2.2019.p241-256

Bawa, G., Feng, L., Chen, G., Chen, H., Hu, Y., \& Pu, T. (2020). Gibberellins and auxin regulate soybean hypocotyl elongation under low light and hightemperature interaction. Physiologia $P, 170(3)$, 345356. https://doi.org/10.1111/ppl.13158

Dewanto, H. A., Saraswati, D., \& Hadjoeningtijas, O. D. (2019). Pertumbuhan kultur tunas aksilar kentang (Solanum tuberosum I.) dengan penambahan super fosfat dan kno3 pada media ab mix secara in vitro. Agritech: Jurnal Fakultas Pertanian Universitas Muhammadiyah Purwokerto, 20(2), 71. https://doi.org/10.30595/agritech.v20i2.3991

Enders, T. A., \& Strader, L. C. (2015). Auxin activity: Past, present, and future. American Journal of Botany, 102(2), 180-196. https://doi.org/10.3732/ajb.1400285

Furnawanthi, I., Devianti, S. J., Nauly, D., Mardiyanto, R., \& Elya, M. (2017). Respon pertumbuhan eksplan kentang (Solanum tuberosum L.) variestas AP-4 terhadap manitol sebagai media konservasi secara in vitro. Prosiding Seminar Nasional 2017 Fakultas Pertanian UMJ, May, 245-252.

Hidayat, Y. S., Efendi, D., \& . S. (2018). Karakterisasi Morfologi Beberapa Genotipe Kentang (Solanum tuberosum) yang Dibudidayakan di Indonesia. Comm. Horticulturae Journal, 2(1), 28. https://doi.org/10.29244/chj.2.1.28-34

Hilman, Y., Suciantini, S., \& Rosliani, R. (2019). Adaptation of Horticultural Crops to Climate Change in the Upland. Jurnal Penelitian Dan Pengembangan Pertanian, 38(1), https://doi.org/10.21082/jp3.v38n1.2019.p55-64

55.

Hou, J., Wu, Y., Shen, Y., Mao, Y., Liu, W., Zhao, W., Mu, Y., Li, M., Yang, M., \& Wu, L. (2015). Plant regeneration through somatic embryogenesis and shoot organogenesis from immature zygotic embryos of Sapium sebiferum Roxb. Scientia Horticulturae, 197, 218-225. https://doi.org/10.1016/j.scienta.2015.09.040

Jahn, L., Hofmann, U., \& Ludwig-Müller, J. (2021). Indole-3-acetic acid is synthesized by the endophyte cyanodermella asteris via a tryptophan-dependent and-independent way and mediates the interaction with a non-host plant. International Journal of Molecular Sciences, 22(5), 1-19. https://doi.org/10.3390/ijms22052651

Joseph K., R., Nabachandra Singh, L., \& Priya Devi, K. (2018). Integration of different sources of organic manure and micro-nutrients on growth, yield and quality of potato (Solanumtuberosum L.) grown under new alluvial soil condition. Indian Journal of Agricultural Research, 52(2), 172-176. https://doi.org/10.18805/IJARe.A-4607

Khalid, A., Arshad, M., \& Zahir, Z. A. (2004). Screening plant growth-promoting rhizobacteria for improving growth and yield of wheat. Journal of Applied Microbiology, 96(3), 473-480. https://doi.org/10.1046/j.1365-2672.2003.02161.x

Kong, E. Y. Y., Biddle, J., Foale, M., Panis, B., \& Adkins, S. W. (2021). The potential to propagate coconut 
clones through direct shoot organogenesis: A review. Scientia Horticulturae, 289(January), 110400.

https://doi.org/10.1016/j.scienta.2021.110400

Li, J., Chai, M., Zhu, X., Zhang, X., Li, H., Wang, D., \& Xing, Q. (2019). Cloning and expression analysis of LoCCD8 during IAA-induced bulbils outgrowth in lily ( Oriental Hybrid 'Sorbonne '). Journal of Plant Physiology, 236(March), 39-50. https://doi.org/10.1016/j.jplph.2019.03.002

Liu, H. Jiu, Huang, C. Ping, Tong, P. Jiang, Yang, X., Cui, M. Ming, \& Cheng, Z. Hui. (2020). Response of axillary bud development in garlic (Allium sativum $\mathrm{L}$.) to seed cloves soaked in gibberellic acid (GA3) solution. Journal of Integrative Agriculture, 19(4), 1044-1054.

$3119(20) 63156-2$

Ludwig-Müller, J. (2011). Auxin conjugates: Their role for plant development and in the evolution of land plants. Journal of Experimental Botany, 62(6), 17571773. https://doi.org/10.1093/jxb/erq412

Lv, Y., Li, Y., Liu, X., \& Xu, K. (2020). Photochemistry and proteomics of ginger (Zingiber officinale Roscoe) under drought and shading. Plant Physiology and Biochemistry, 151(October 2019), 188-196. https://doi.org/10.1016/j.plaphy.2020.03.021

Martínez-López, M., García-Pérez, A., Gimeno-Páez, E., Prohens, J., Vilanova, S., \& García-Fortea, E. (2021). Screening of suitable plant regeneration protocols for several capsicum spp. Through direct organogenesis. Horticulturae, 7(9). https://doi.org/10.3390/horticulturae7090261

Méndez-Hernández, H. A., Quintana-Escobar, A. O., UcChuc, M. A., \& Loyola-Vargas, V. M. (2021). Genome-Wide Analysis, Modeling, and Identification of Amino Acid Binding Motifs Suggest the Involvement of $\mathrm{GH} 3$ Genes during Somatic Embryogenesis of Coffea canephora. Plants, 10(10), 2034. https://doi.org/10.3390/plants10102034

Meng, C., Wang, F., Yang, K., Shock, C. C., Engel, B. A., Zhang, Y., Tao, L., \& Gu, X. (2020). Small wetted proportion of drip irrigation and non-mulched treatment with manure application enhanced methane uptake in upland field. Agricultural and Forest Meteorology, 281(October 2019). https://doi.org/10.1016/j.agrformet.2019.107821

Moriwaki, T., Falcioni, R., André, F., Tanaka, O., Aparecida, K., Cardoso, K., Souza, L. A., Benedito, E., Rafael, M., Moacir, C., Camargos, W., \& Vegetal, L. D. E. (2019). Nitrogen-improved photosynthesis quantum yield is driven by increased thylakoid density, enhancing green light absorption. Plant Science, 278(July 2018), 1-11. https://doi.org/10.1016/j.plantsci.2018.10.012

Munggarani, M., Suminar, E., Nuraini, A., \& Mubarok, S. (2018). Multiplikasi Tunas Meriklon Kentang Pada Berbagai Jenis dan Konsentrasi Sitokinin. Agrologia, 7(2). https://doi.org/10.30598/a.v7i2.766

Nawaz, K., Chaudhary, R., Sarwar, A., Ahmad, B., Gul, A., Hano, C., Abbasi, B. H., \& Anjum, S. (2021). Melatonin as master regulator in plant growth, development and stress alleviator for sustainable agricultural production: Current status and future perspectives. Sustainability (Switzerland), 13(1), 125. https://doi.org/10.3390/su13010294

Naz, M., Sughar, G., Soomro, Z. A., Ahmed, I., Seema, N., Nizamani, G. S., Saboohi, \& Nizamani, M. R. (2017). Somatic embryogenesis and callus formation in sugarcane (Saccharum SPP L.) using different concentration of 2, 4-D and RAPD analysis of plants regenerates. Indian Journal of Agricultural Research, 51(2), 93-102. https://doi.org/10.18805/ijare.v0iOF.7637

Parab, A. R., Chew, B. L., Yeow, L. C., \& Subramaniam, S. (2021). Organogenesis on apical buds in common fig (Ficus carica) var. Black Jack. Electronic Journal of Biotechnology, 54, 69-76. https://doi.org/10.1016/j.ejbt.2021.10.001

Ryu, C. M., Hu, C. H., Locy, R. D., \& Kloepper, J. W. (2005). Study of mechanisms for plant growth promotion elicited by rhizobacteria in Arabidopsis thaliana. Plant and Soil, 268(1), 285-292. https://doi.org/10.1007/s11104-004-0301-9

Sevillano, D., Romero-Lastra, P. T., Casado, I., Alou, L., González, N., Collado, L., Domínguez, A. A., Arias, C. M., Corvillo, I., Armijo, F., Romero, M., \& Maraver, F. (2018). Impact of the biotic and abiotic components of low mineralized natural mineral waters on the growth of pathogenic bacteria of human origin: A key to self-control of spa water quality. Journal of Hydrology, 566(September), 227234. https://doi.org/10.1016/j.jhydrol.2018.09.008

Tohge, T., Watanabe, M., Hoefgen, R., \& Fernie, A. R. (2013). Shikimate and phenylalanine biosynthesis in the green lineage. Frontiers in Plant Science, 4(MAR), https://doi.org/10.3389/fpls.2013.00062

Vandenbussche, F., Vriezen, W. H., Smalle, J., Laarhoven, L. J. J., Harren, F. J. M., \& Straeten, D. Van Der. (2020). Ethylene and Auxin Control the Arabidopsis Response to Decreased Light Intensity 1. Plant Physiology, 133(October 2003), 517-527. https://doi.org/10.1104/pp.103.022665.and

Wang, D., Cheng, L., Wang, Y., \& Zhang, F. (2018). Comparative Proteomic Analysis of Potato (Solanum tuberosum L.) Tuberization In Vitro Regulated by IAA. American Journal of Potato Research, 95(4), 395-412. https://doi.org/10.1007/s12230-018-96406

Xu, X., Van Lammeren, A. A. M., Vermeer, E., \& Vreugdenhil, D. (1998). the Role of Gibberellin, Abscisic Acid, and Sucrose in the Regulation of Potato Tuber Formation in Vitro. Plant Physiology, $117(2)$, https://doi.org/10.1104/pp.117.2.575

Zahid, N. A., Jaafar, H. Z. E., \& Hakiman, M. (2021). Alterations in microrhizome induction, shoot multiplication and rooting of ginger (Zingiber officinale roscoe) var. bentong with regards to sucrose and plant growth regulators application. Agronomy, https://doi.org/10.3390/agronomy 11020320

Zhang, Z., Zhou, W., \& Li, H. (2005). The role of GA, IAA 
and BAP in the regulation of in vitro shoot growth and microtuberization in potato. Acta Physiologiae

Plantarum, 27(3), 363-369.

https://doi.org/10.1007/s11738-005-0013-7 